\title{
ZIEGLER ÁGNES: A BRASSÓI FEKETE TEMPLOM. REFORMÁCIÓ ÉS RENOVÁCIÓ. FELEKEZETI, VÁROSI, RENDI CSOPORTIDENTITÁS KIFEJEZŐDÉSE EGY ÚJJÁSZÜLETŐ ÉPÜLETBEN. MARTIN OPITZ KIADÓ, BRASSÓ-BUDAPEST 2018. 319 LAP, 188 KÉP
}

Ziegler Ágnes könyve, A brassói Fekete templom szokatlan felütéssel kezdődik. Arról az élményről ír, amelyet a templomépület látványa kelt a szemlélőben. Már az is meglepő, ha egy művészettörténész be meri vallani, hogy személyes élményt jelent neki valamely müalkotás. Ez a vallomás azonban nem szépelgés vagy retorikai gyakorlat, hanem a mondanivaló lényegéhez tartozik. Aki ugyanis járt Brassóban és látta - akárcsak kívülről is - a Fekete templomot, maga is megtapasztalhatta azt, amit a Szerző megpróbált szavakkal fölidézni. Az épület hatalmas tömbje ma is uralkodik a város fölött, betölti a szűk völgy közepét. Az utolsó nagy gótikus templom ez, kelet felé. Itt ér véget Európa, szoktuk mondani kicsit nehéz szívvel. Belépve - emlékszem, a Mûvészettörténeti Intézet tanulmányi kirándulásán jártam ott először - zavarba jöttünk: hol itt a gótika? Kerestük a megbízható részleteket, és lassan rá kellett ébrednünk, hogy szinte minden, amit látunk, későbbi renováció eredménye. Hittük is, nem is. A berendezés kápráztatott el még bennünket, a stallumok, és főképp a keleti szőnyegek fantasztikus sorozata (1. kép). Valahogy minden magyarázatra várt.

Ha már azzal az élménnyel kezdtem, ami a lényeghez tartozik, akkor itt legelöl szeretném kiemelni azt, amire a könyvismertetések végén szoktunk kitérni: a kötet nyomdai kiállítása ragyogóan sikerült. Ez az erős vizuális hatás az illusztrációknak és a tördelésnek köszönhető. Nagyon jók a fényképfelvételek, a minőség és a válogatás is, sehol semmi kényszeres, és a nyomtatás minősége is kiváló. A Martin Opitz Kiadó igen gondos munkát végzett. Aki csupán végiglapozza a könyvet, az előtt is világossá válik a brassói főtemplom nagyszerüsége, berendezésének párját ritkító gazdagsága. Művé- szettörténeti pozíciója is. A fedélszék belsejéről készült kép például minden felmérési rajznál, precíz szövegnél meggyőzőbben mutatja be az együttes monumentalitását, éreztetve a 18. századi ácsmunka dimenzióit. Az illusztrációk között a szigorúan tudományos, mondhatni rendőrségi fotók dominálnak persze, a textilek vagy az ötvösmúvek képei, vagy a sírkövek sorozatáé. Csoportjaiknak önálló a

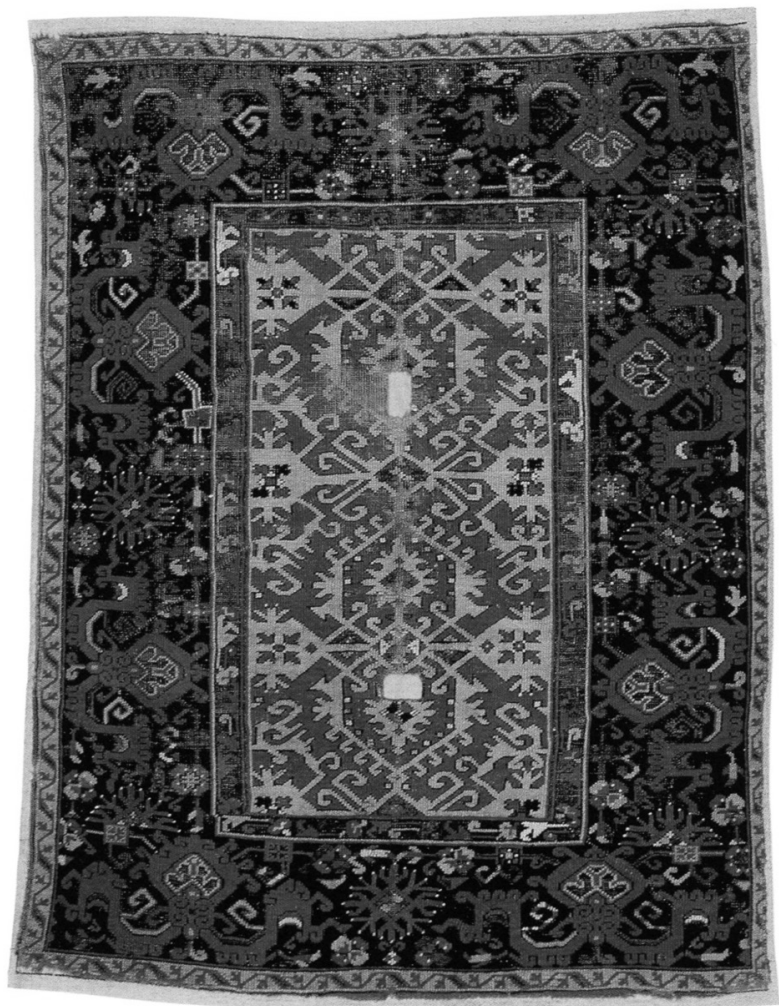

1. Lorenzo Lotto szônyeg a brassói Fekete templomból, Usak, 17. század vége 
mondandójuk, képi eszközökkel ismétlik a narratívát. Van úgy, hogy a szövegben nincs is sok fogódzó, mint épp a síremlékek esetében, amelyek csak a Katalógusban szerepelnek.

A síremlékek is részei a templom formailag nehezen datálható részleteinek, amelyek magyarázatra szorulnak. Ziegler Ágnes monográfiája most mindehhez kulcsot ad. Különös könyv, elég végigfutni a tartalomjegyzéken. A struktúrája ugyanis nem statikus, hanem dinamikus; nem kronológiai vagy topográfiai rendben „darálja le” az anyagát, ahogyan egy hagyományos épületmonográfiától várnánk, hanem időrendi átfedésekkel, ugrásokkal többször újra indulva. Olyan szavakat olvashatunk itt, mint „társadalmi csoportok a templomtérben”, „téralkotás”, „felekezeti identitás”, „konfesszionalizáció” és így tovább. A szempontok váltakoznak, és engem a Szerző meggyőzött, hogy ennek a templomnak másképp nem is lehetett volna megírni a történetét.

A Bevezetô módszertani kérdéseket tárgyal: arra a kérdésre keresi a választ, hogy miért nem szerepel ez a rendkívüli épület szinte sehol a nagy stílustörténeti összefoglalásokban. Itt kapott helyet a templomról szóló irodalom historiográfiája és az épület attól elválaszthatatlan praktikus kutatástörténete. Áttekinti a műemléki helyreállításokat a közelmúltig; azután sorra veszi a képi, a levéltári forrásokat, illetve magát az épületet mint forrást. Jól látjuk a templom tudománytörténeti helyét: gótikusnak nem igazán gótikus, jóllehet tömege, határoló falai tükrözik a középkori állapotot; ám barokknak sem lehet mondani, hiába készült lényegében a 18. században, annyira ragaszkodik saját előzményeihez. Már ebben a fejezetben világossá válik: a könyv igen korszerü munka, nem csupán egy régi épület építéstörténete, berendezésének leírása, hanem mindennek funkciója, oka van, mondhatni in actu ábrázolja a templomot. Bárcsak követné több ilyen mü. A kolozsvári Szent Mihálynak nincs monográfiája, de nincs például a győri székesegyháznak vagy a pécsinek sem. Magyarországon klasszikus templommonográfiát hetven éve írtak utoljára. Nem ezek a maguk korában időszerü (és utolérhetetlen színvonalú) munkák - köztük Entz Géza gyulafehérvári székesegyháza vagy Balogh Jolán Bakóczkápolnája - voltak azonban Ziegler Ágnes müvének a mintái. A könyv korszerüségét az biztosítja, hogy a szerző otthonosan mozog a modern - elsősorban a német - szakirodalomban.

Ezután következik a második fejezet, címe szerint A templom története. Kiindulópontja a 20. századi restaurálások krónikája, ezt követi az épület leírása. Ez megint dinamikus narratíva. A száraz leírás kideríti, hogy szinte minden, amit látunk, a 18. századi helyreállításkor keletkezett. A karzatok, a boltozatok, a pillérek, vagyis az épület túlnyomó része. Régi, gótikus munkának a kapukeretek tarthatók, meg a főfalak nagy szakaszai, kívülről tekintve. Mindezt világosan megmutatva válik lehetségessé a rejtőzködő középkori templom építéstörténetének nyomon követése. Csak nyomokról van ugyanis szó, amelyek a 14. századi épületből megmaradtak. A templomot - amely eredetileg ugyanakkora volt, mint a mai - 1532-ben újra kellett boltozni, valószínűleg egy erős földrengés után. Ez már egybeesik a reformáció időszakával, ami Brassóban elválaszthatatlan Johannes Honterus személyétől. Annak a pontos dátumát azonban, hogy Brassóban a katolicizmust mikor váltották fel a lutheri hitelvekkel, nem lehet tudni. 1542-ben mindenesetre a plébános megnősült, és ekkortájt az egész Barcaság áttért az új hitre. 1544-ben a templomból kidobták a mellékoltárokat és csak a főoltárt hagyták meg. Bár a 16. század közepe történéseinek szinte minden emlékét elhamvasztotta a későbbi tüzvész, a brassói reformáció kezdetei a könyv egészét meghatározzák. Talán nem fogok nagyon mellé, ha úgy gondolom, hogy az utóbbi évtizedek intenzív konfesszionalizáció-kutatása alakította át a brassói templom monográfiáját ennyire izgalmas könyvvé.

A harmadik nagy fejezet a tüzvésszel foglalkozik. Drámai a címe: A tüzpusztítás. Bevezetésül távolról indít: áttekinti Erdély történetét a fejedelmi kor végén, kitérve a szász nemzet csapdahelyzetére: nemzeti és felekezeti identitásának megőrzésére az új, a katolikus Habsburg-berendezkedésben. Az átrendeződés kellős közepén, 1689. április 21-én tört ki a tüzvész, amely a város jelentős részét és a plébániatemplomot elpusztította. Megint nagyon impresszionáló, hogy a Szerző számára a tűzvész történetének feltárása, újramondása sem statikus, hanem mozzanatos, több rétegü történet. Az írásos forrásokat ismertetve ugyanis nem rest retorikai elemzést végezni, feltárni az írott szövegek toposzait, mindezt természetesen azért, hogy minél pontosabban értsük, mi maradt a középkori templomból. Kevesen tudják, hogy csak így érdemes forrásokat olvasni.

A pusztítás felmérése után következik a negyedik fejezet, A templom újjáépitése. Kezdi - miként annak idején maguk a brassóiak - a tetőszerkezettel, amely az épület falait védi. Először a szentélyt fedték be (amint lehet, újra indult a hitélet), majd a hajót. A boltozatokat évtizedekig nem újították meg. A főhajót kísérő karzatok problémája lényeges pont: úgy túnik fel - s ez a logikus -, hogy ezeknek nem volt középkori elözményük, csupán a lutheránus gyakorlatban volt rájuk szükség. A karzatot tartó boltozatoknak a hajóba nyíló homlokíve azon- 
ban hangsúlyozottan gótizál. A faragott kőelemek gondos stiláris elemzése rengeteg analógiát vonz ide. Legmeglepőbb, hogy az ornamentika legjobb, meggyőző párhuzamai a Kárpátokon túl kerülnek elő, az ottani ortodox egyházi épületeken. Nagyon is kézenfekvő az a feltételezés, hogy a hegyeken túl az igényes építkezésekhez reprezentatív kőfaragványokat Erdélyből importáltak, illetve tapasztalt kőfaragókat erdélyi városokból hívtak. A jelenség hasonló az ötvösművek megrendeléséhez: azt régóta tudjuk, hogy a brassói ötvösök dolgoztak román ortodox egyházi megrendelésekre is. A mesterek természetesen alkalmazkodtak a megrendelő igényeihez. Itt az akkulturáció klasszikus esetéről van szó, színtiszta müvészettörténeti problémaként. Megkockáztatom: az archaizálására is mostanában nyílt rá a szemünk, s ennek épp Erdélyben korábbi példái is vannak: tulajdonképpen a Lázói-kápolnától sem tagadhatjuk meg ezt az irányt, de kivált nem a Várday-kápolnától, s Várday Ferenc egyéb építkezéseitől sem a gyulafehérvári székesegyházban.

Nagyon izgalmas a kőszószék esete is (2. kép). Teljesen új építmény (a régi elpusztult), a felsorolt erdélyi analógiák abszolút meggyőzők. Modern a maga módján, vagyis régies; ha van valami késő reneszánsz ebben a templomban, akkor ez biztosan az. A liturgikus tér egyik centruma az igehirdetés helye, a másik az oltár; az ezek köré meghatározott rendben csoportosuló stallumok - a városi magisztrátusé, a céheké - jó része elpusztult, mai helyük nem tükrözi az eredetit. A mostani berendezésből kiindulva itt is érdekfeszítő történet kerekedik ki; semmi sem mozdulatlan. A bútorok, a szőnyegek, a paramentumok egykori használata tárul fel előttünk. A Szerzőnek ezen a ponton is sikerült a sokféle szempontból egységes, izgalmas narratívát összeállítani. A 19. századi, neogótikus berendezési tárgyak már nem részei a könyvnek; ez önkorlátozás is, ítélet is. Látva az eredményt, nem hiányzik.

A kötet mintegy harmadát a Katalógus teszi ki. Ebben azok a berendezési tárgyak szerepelnek (nem mind), amelyek a nagy tüzvész utáni időszakra jellemzők. Méretek, anyag, datálás, irodalom: a klasszikus katalógustételek szerint. Mindenről van nagyméretű kép. Stallumok, kapuszárnyak, a szószék, mintegy negyven török szőnyeg, a kazulák és pluviálék sorozata. A textilek fantasztikusak: a szőnyeg-kollekció a legnagyobb templomi együttes Európában, és egy múzeumnak is becsületére válnék ennyi. A kazulák híre még nagyobb. Emlékszem, amikor Lipcsében jártam, Evelin Wetter épp akkor foglalkozott a meghatározásukkal, és szervezte a restaurálásukat. Öt szerepel itt, mindegyik barokk brokátra applikált középkori kazulakereszttel, brokát alapjuk azonban középkori sza-

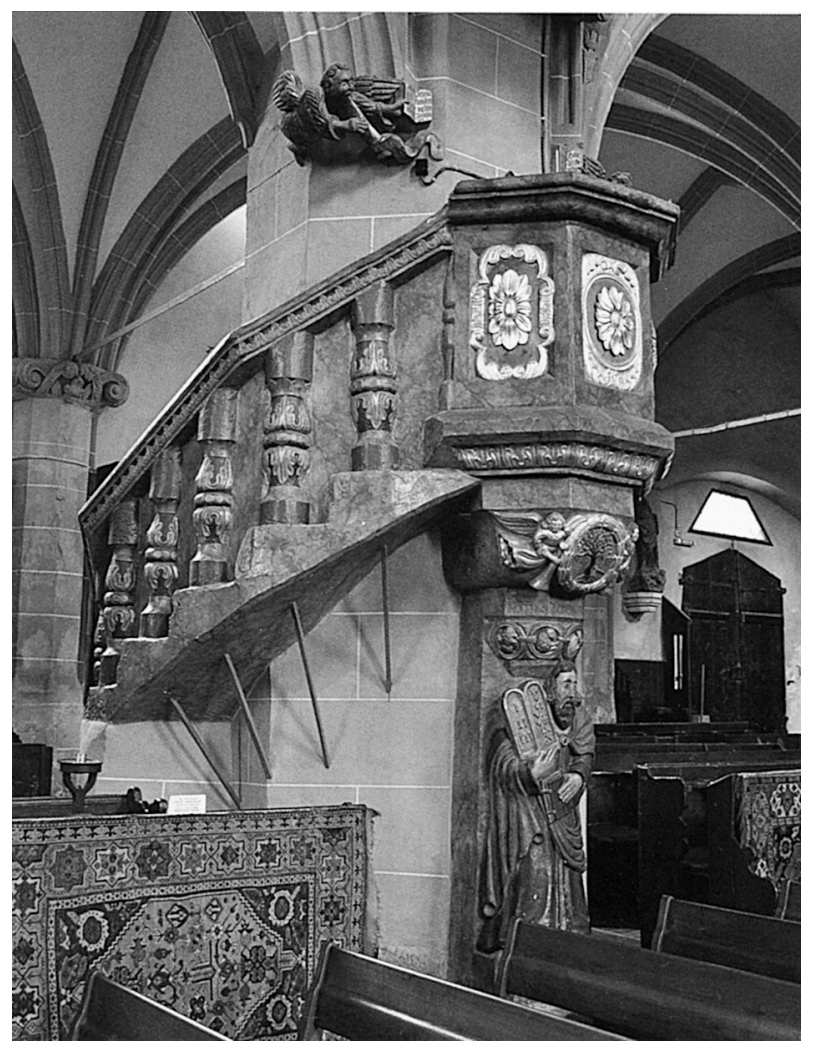

2. A brassói Fekete templom szószéke, 1696

bású. Azokat a mintákat követték, amelyek a templomban maradtak fenn, modernizálatlanul (3. kép). Nagyszebenben is megörződtek ilyenek, azoknak alapszövetük is középkori, s ezeket szokták több-

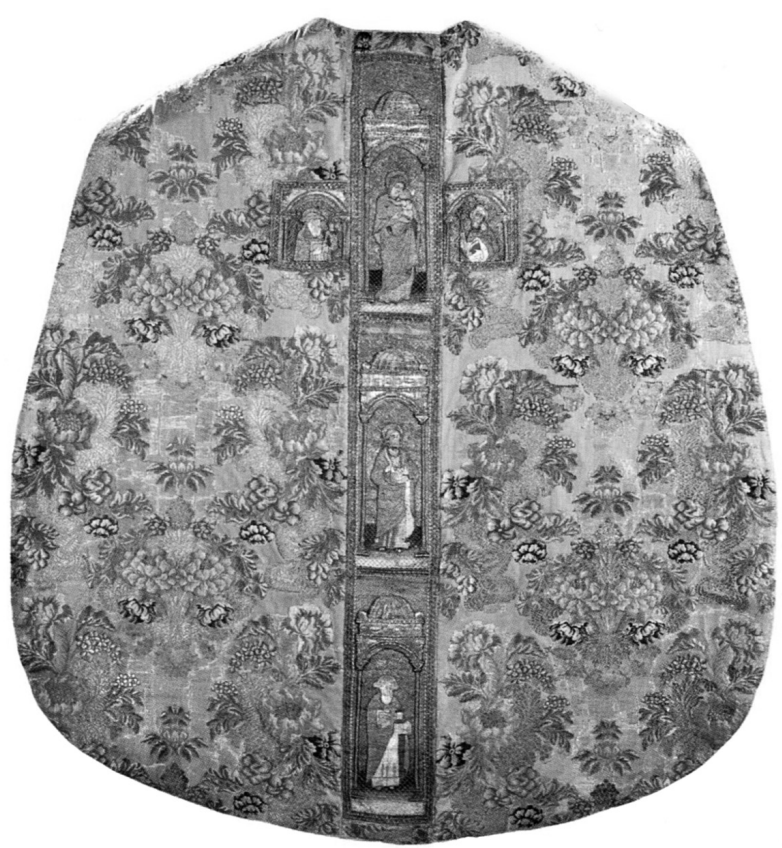

3. Kazula a brassói Fekete templomból; keresztje 1500 körül, selyemszövete 1740-1750 


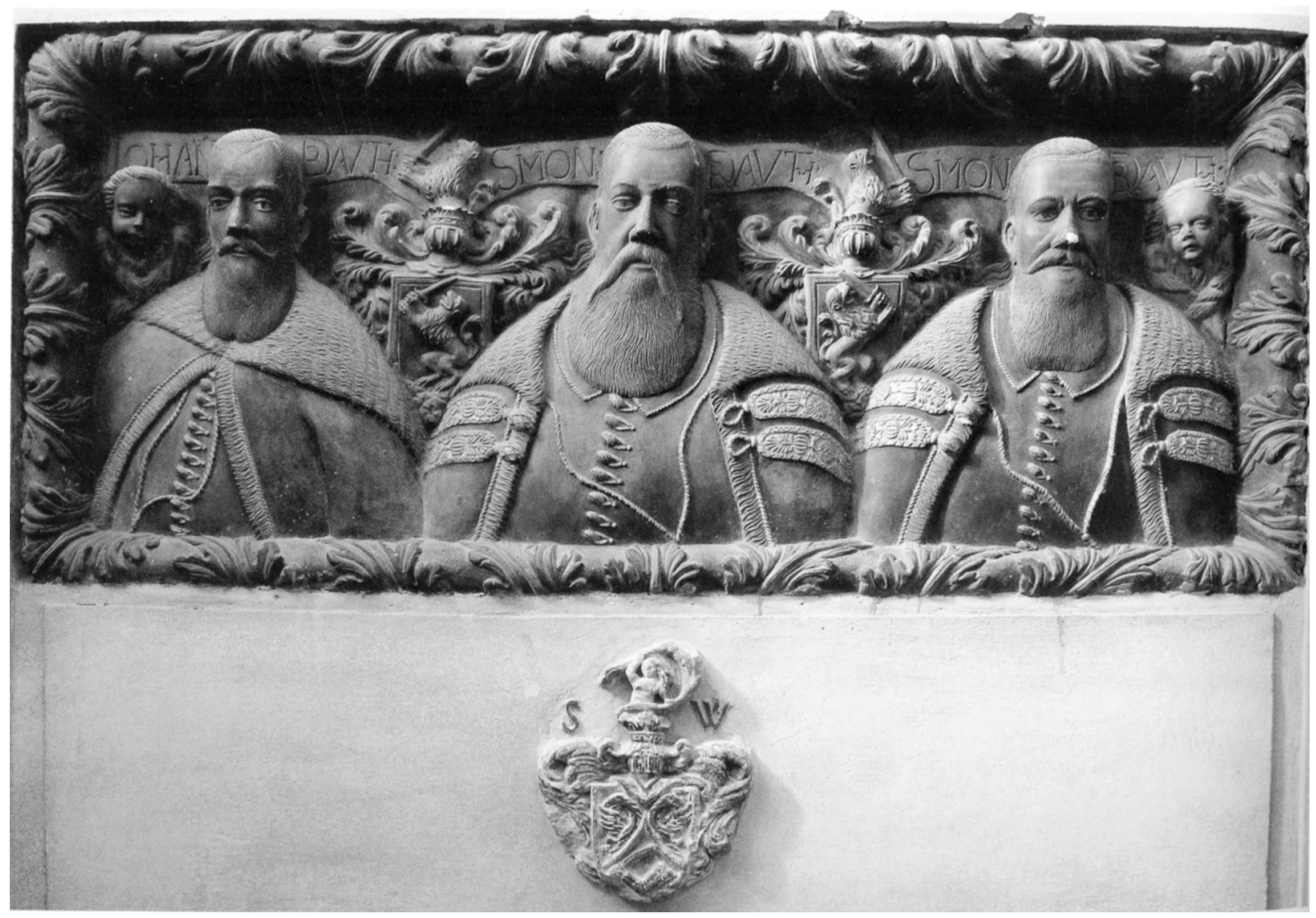

4. Johann Drauth, Simon Drauth és Simon Drauth közös síremléke a brassói Fekete templomban, 1690 körül

ször reprodukálni. Balogh Jolán Erdélyi renaissanceában is benne vannak. Tanulságos, ahogyan a középkori textileket kiválogatták hasznosításra a lutheránusok. Csak a kazulák és a pluviálék maradtak használatban, speciális használatban tudniillik, amint ezt a szertartáskönyvekből és az egyházi feladatleírásokból tudni lehet. A lelkészek az istentiszteleten magukra öltötték a régi darabokat, feltehetőleg úrvacsoraosztáskor a kazulát, úrvacsoraosztás nélküli ceremóniákon a pluviálét. Még a katolikus idők liturgikus színeit is követték. A többi textil (sok dalmatika, cappa, stóla stb.) raktárra került, és utóbb darabjaikat felhasználták a többi javítására. A paramentum-együttest a sekrestyében őrizték, hasonlóan a szőnyegekéhez, ezért nem pusztultak el a túzvészben. A különleges liturgikus ruhahasználat jól megkülönböztette a brassói lutheránus gyakorlatot a radikálisabb felekezetekétől - a reformátusok vagy az unitáriusok körében az ilyesmi elképzelhetetlen lett volna -, s egyben a városi polgárság múltját, identitását is reprezentálta. A reformáció idején az ötvösmúveket is kiválogatták: csak azt tartották meg a templomban, amit használtak, vagyis a kelyheket, a paténákat, a gyertyatartókat és a kereszteket. A többit hasznosításra átadták a városi tanácsnak. Úgy tünik fel, hogy a templom kincsei sem pusztultak el a túzvészben, és sorozatuk a 18. században tovább bővült. Ezek azonban tipikus barokk munkák, a kannák is, kelyhek is. A brassói ötvösség története nagyon fontos fejezete a magyarországi kora újkori ötvösségének.

Tucatnyi sírkő zárja a Katalógust; jelentős részük eddig közöletlen volt. Látványosan kötődnek a 17. századi erdélyi szász hagyományhoz. Ha nem volnának évszámosak, datálhatnánk őket akár korábbra is. A címeres-feliratos lapok kortalanok szinte, és nem igazán keltik fel a múvészettörténészek érdeklődését, a figurálisok annál inkább (4. kép). A brassói sírkövek most fognak bekerülni a müvészettörténeti kánonba.

A könyvet gazdag levéltári jegyzék (mintegy száznegyven regesztával), illetve bibliográfia, képjegyzék zárja, valamint román- és német nyelvú összefoglalás. A hely- és személynévmutató jelentősen megkönnyíti a kötet tudományos használhatóságát.

Ziegler Ágnes könyvének eredetije doktori diszszertációja volt, amelyet Budapesten, az ELTE Művészettörténeti Tanszékén védett meg 2012ben. A vita szövegét közölte a Művvészettörténeti Értesítő 2013-ban. Minderre kitér Marosi Ernő (a Szerző témavezetője), aki a mostani kötet ajánlá- 
sát, fülszövegét írta. S ha az ELTE és Marosi Ernő nevét idézzük, akkor idézzük Kovács Andrásét, a tudós professzorét is, akinek kolozsvári iskolájából, a Babeş-Bolyai Egyetemről Ziegler Ágnes tudományos pályája elindult, s akinek útmutatása annak idején a témaválasztást is befolyásolta. Zárásképp hadd parafrazáljam Marosi Ernő egy korábbi, privát megjegyzését: végre magyarul jelent meg egy ránk (is) tartozó, régi művészetet tárgyaló monográfia. Ezek ugyanis az utóbbi években nem itt jelentek meg. A magyarországi késő középkori ötvösség modern monográfiáját Evelin Wetter írta meg s adta ki Lipcsében németül (2011), az erdélyi középkori szentségházak német nyelvű, kiváló monográfiáját German Kinga Németországban adta ki (Michael Imhof Verlag, 2014), Sarkadi Emesének az erdélyi szárnyasoltárokat feldolgozó korpusza angolul jelent meg szintén Lipcsében (2012). A most Brassóban és Budapesten kiadott Fekete templommonográfiával beálltunk végre a sorba. A magyar nyelvú megjelenés nem akadálya annak, hogy egy könyv idegen nyelven is kijöjjön. De a magyar múvelődésnek és a tudománynak - ha azon nem csupán a szűk, pár embernyi szakmát értjük - csak így lesz integráns része.

Mikó Árpád 